\title{
An Ethnobotanical Survey of Medicinal Plants Used by Traditional Healers of Kaprada Forest (Valsad District), Gujarat, India
}

\author{
C. Patel Dharmesh* and B.L. Jat
}

Bhagwant University, Sikar Road, Ajmer (Rajasthan), India

*Corresponding author

\section{A B S T R A C T}

\section{Keywords}

Ethnobotany, Medicinal plants, Kaparada forest, Gujarat.

Article Info

Accepted:

15 June 2018

Available Online:

10 July 2018
The selected study area is Kaprada forest, Valsad district in Gujarat state. The study was aimed to document the traditional healer's knowledge of the local people about the uses of different plant parts through personal interview. The study was focus on identify medicinal plants, which parts of the plant is used, method of preparation, diseases treatment method. The data collected reveled that about 50 plant species belongings to 33 families were recorded to use of medicinal uses. The common diseases treated by the traditional healers like mouth diseases, liver disorder, sexual debility, diabetes, skin diseases, gynecological problem, eye diseases, heart diseases, dengue, fever, kidney stone problem, digestive disorder and pancreases.

\section{Introduction}

Ethnobotany deals with the study of total natural and interrelationship between men, plants and domesticated animals. Plants since time immemorial have been used globally as valuable and safe natural resource of medicine. The main traditional medicinal system includes ayurveda, sidha and unani. The Rig-Veda, dating between 3500B.C. to 1800B.C, is the earliest recorded information on medicinal plants. India is one of the 17 mega biodiversity countries in the world. It has 45000 plant species, out of which 1500020000 plants have medicinal values. In India, plants have been used for medicinal purposes since ancient time, as mentioned in Ayurveda. The traditional knowledge of herbs is famous among the indigenous and local people. The traditional healers are the main source of information on medicinal importance of plants. The rural population has immense faith for traditional and magical herbs. The rural people have traditional indigenous knowledge about the use of medicinal plants to cure various diseases.

India is very rich in ethnobotanical heritage. There are over 400 different tribal and other ethnic groups in India. Part of the tribal groups, many other forest dwellers and rural people also possess unique knowledge about 
plants. A fragment of such folklore and traditions have also survived among urban societies (Patel, 2002). Proper documentation enables its validation, quantification and spread of this valuable knowledge.

There are several studies from India on medicinal plants and their indigenous uses. Kirtikar and Basu (1993) compiled information on Indian medicinal plants in four volumes. Rastogi and Mehrotra (1991-1998) designed a companion volume of Glossary of Indian medicinal plants. (Chopra et al., 1956) In which each plant's chemical and biological aspects were discussed in detail with their distribution in India. Jain (1991) prepared the Ethnobotanical dictionary in which Ethnobotanical use of 1174 genera were complied. The Ethnobotanical studies of different tribal localities may lead to find new information on unexploited natural resources as sources of medicine, food etc. Jain et al. (2005) listed 243 species of medicinal plants in Sitamata wildlife sanctuary, being utilized in curing different ailments, out of which 34 remedies based on 24 medicinal plants were new.

Inamdar (1966) had explored the entire Dharampur forest and first preliminary survey of flora of Dharampur forest was brought in to the knowledge of botanical Society. Vora (1980) have again attempted a floristic survey of Dharampur Taluka of Valsad District. However, Reddy (1987-Ph.D Thesis) had made a comprehensive study on the Flora of Dharampur forest. He recorded 879 angiosperms belonging to 484 genera under 110 families. Despite of this a very little information is available in Cookes Flora of Bombay Presidency (1958-reprint). Shah (1978) mentioned many species in south Gujarat region; however exact localities of plants of Kaprada had been cited for a few plants. In addition to that a few more about 45 more research papers were available on the floristic of the Kaparada forest. However an ethnobotanical record of the present study area is very poor. This area study was, Patel (2011Msc Thesis). Medicinal Plant Diversity and Ethnomedicobotany of Kaprada range of Dharampur Forests in South Gujarat. A perusal of the literature reveals that only two research papers (Gohil and Thakor, 2008 and Rao et al., 2013) has been published covering the ethnobotanical information on a very few plants of the Kaprada Taluka. Kaprada is a very rich forested area in terms of plants diversity which harbors many valuable medicinal plants and tribals of the study area are using these plants since ancient time which is yet to record in a proper scientific way.

The detailed information on medicinal uses of plants is not available or not recorded well. So the present scenario suggests that these gaps should be full filled urgently. Many of the plants were proved to be the important sources of food, fodder, fiber, medicine etc.

\section{Materials and Methods}

The Kaprada forest is very rich in biodiversity. The taluka of Kaprada is separated from Dharampur on 15th October, 1997. Kaprada taluka is situated on 20.43' - 20.13' North latitude and 73.42' - 73.01' East longitude. Elevation: $41 \mathrm{mts}$, above Sea level (MSL). Its North boundary is shared with Dharampur taluka, North-West boundary with Pardi taluka while East and South East boundary with Maharashtra State and South-West boundary with Silvassa and Dadra and Nagar Haveli. Its Geographical area is $936.62 \mathrm{Sq}$. Kms. and forest area is about $476.58 \mathrm{Sq}$. Kms. according to State government of Gujarat which is $50 \%$ of the Geographical area. It shows how the area is rich by plant diversity. Kaprada taluka is having Par, Kolak and Damanganga rivers to keep it green whole the year. Kaparada is divided into two zones one is the Talat and the second is Dungar region toward the east this 
taluka has a region where the land bears much dissected and poorer appearance. Deeply furrowed streams and river zig-zagging through the low hills are a common sight. The hills and slopes are covered with forest, once dense but a good deal depleted now due to indiscriminate felling. The region is shaped like a plateau has quite a few high hills with lofty peaks. This "Dungar" region is the home to Koknas, nayka and the Warlis - three schedule tribes inhabiting majority of the taluka. Forest department at Dabkhal play very important role on conservation of Kaprada forest. Kaprada is main town for the Kaprada taluka and also taluka head. Kaprada is $43.7 \mathrm{~km}$ distance from main city of Valsad district.

\section{Types of soil}

The soil of the Kaprada forest is a mixture of clay and murrun. Due to basaltic formation the soils are red loam and black soil, which are heterogamous in colour. Red shallow soil found in slopes area, dark brown deep soil on the plains and it is sandy and calcareous along the rivers. Plain areas soil is fertile compare to slope area soil.

\section{Climate}

Monsoon, winter and summer are the three seasons. The climate is consistent in a season in all areas. Monsoon approaches from SouthWest direction and commences from second half of the month June and lasts up to the month September. Average rainfall ranges between 1000 to $3000 \mathrm{~mm}$. Period of rainfall is from June to September and sometimes it extends up to October also. The interior part of the forest are much unhealthy and malarious during monsoon and subsequent months also. Coldest months are November January. The temperature ranges between 12 $\mathrm{C}$ minimum in winter to $42.8 \mathrm{C}$ maximum in summer. Climate is warm, humid and equable at the top of the hills, but it is hot in the valleys. Summer starts from the month of February or March and last up to the midweek of June. There is Diversity in land region as this area consists of fertile land, forest area and some part that is undulating with hills. The forest is of moist deciduous type forest.

\section{Exploration and data collection}

The study was conducted in the year 20152018. Many field trips were conducted, each of 05-10 days duration. The information on ethnomedicinal plants was gathered through interviews with knowledgeable local inhabitants who possess the knowledge on different plants growing wild in and around their villages. They are locally called as "Bhagats". Because of the fact that the majority of the population is illiterate, oral interviews were held in the villages and the derived information was recorded, as per the basic methodologies described by Martin (1995) and Cotton (1996). The information regarding the local names of useful plants, ailments and mode of use etc., are systematically documented for ethnomedicinal species. When the "Bhagats" were treating the patients, the plants used in treatment, method of preparation of medicine and the mode of application etc., were recorded in the field note book. The information gathered from one person was cross-examined by repeated interviews with users. Personal information about the healers like name, age, village and the number of patients treated by them, were also collected for each informer for authenticity of the information. Photographs of ethnomedicinal plants are also taken with the help of Sony Digital camera having 14X zoom lens, to depict significant morphological features of ethnomedicinal species. The samples of ethnomedicinal plants were also collected during the field visits for determining correct identity and preparation of voucher specimen. The study area has been 
thoroughly surveyed in all seasons to procure maximum Collections and their variants. The fieldwork consisted of collection of plant specimens for herbarium, observation on the habit, habitat, phenology and distribution. The herbarium specimens were processed with Mercuric chloride-alcohol saturated solution. The collected plant samples were processed and identified using the floristic literature pertained to Gujarat (Shah, 1978; Patel, 1971) and the neighboring Maharashtra State (Almeida, 2003).

\section{Results and Discussion}

In survey totally collected 60 species belonging to 33 families. In which herb have 17 species, shrubs have 4 species, trees have 14 species, climbers have 10 species and rhizomes have 5 species. Plants belonging to different families viz- Acanthaceae, Amaranthaceae, Amaryllidaceace,
Anacardiaceae, Apocynaceae, Asclepiadaceae, Asteraceae, Bignoniaceae, Caesalpiniaceae, Caricaceae, Convolvulaceae, Crassulaceae, Cucurbiataceae, Euphorbiaceace, Fabaceae, Lamiaceae, Lythraceae, Malvaceae, Meliaceace, Menispermaceae, Mimosaceae, Moringaceae, Nelumbonaceae, Periplocaceae, Piperaceae, Poaceae, Rubiaceae, Rutaceae, Scrophulariaceae, Solanaceae, Trapaceae, Ulmaceae, Verbenaceae and Zingiberaceae. 50 plants were enumerated with their medicinal importance. A tribal person has good knowledge about the uses of many plants. They were using these plants to cure diseases like mouth diseases, liver disorder, sexual debility, diabetes, skin diseases, gynecological problem, eye diseases, heart diseases, dengue, fever, kidney stone problem, digestive disorder and pancreases. Tribal people are also being living in spiritualism for which they utilize many ethnomedicinal plants.

Table.1 Study in ethnomedicinal plants of Kaprada forest, Valsad district, Gujarat, India

\begin{tabular}{|c|c|c|c|c|c|}
\hline $\begin{array}{l}\text { Sr. } \\
\text { no }\end{array}$ & Botanical name & $\begin{array}{l}\text { Local } \\
\text { Name }\end{array}$ & Family & $\begin{array}{l}\text { parts } \\
\text { used }\end{array}$ & Ethnobotanical uses \\
\hline 1 & Abrus precatorius (L.) & Chanothi & Fabaceae & Leaf & $\begin{array}{l}\text { Fresh leaves or dried leaves are } \\
\text { chewed to cure mouth sores. }\end{array}$ \\
\hline 2 & $\begin{array}{l}\text { Acacia nilotica (L.) Del. } \\
\text { subsp. indica (Benth.) } \\
\text { Brenan. }\end{array}$ & Deshi & Mimosaceae & $\begin{array}{l}\text { Leaf, } \\
\text { Gum }\end{array}$ & $\begin{array}{l}\text { Fresh leaves are chewed twice a day } \\
\text { in mouth sores and mouth ulcers. } \\
\text { Gum is used liver tonic. }\end{array}$ \\
\hline 3 & $\begin{array}{l}\text { Achyranthes aspera } \mathrm{L} \text {. } \\
\text { var. aspera }\end{array}$ & Anghedi & Amaranthaceae & $\begin{array}{l}\text { Leaf, } \\
\text { whole } \\
\text { plat }\end{array}$ & $\begin{array}{l}\text { Plant ash mixed with sesame oil is } \\
\text { used for treatment of ear diseases. } \\
\text { Fresh leaves are taken on empty } \\
\text { stomach in cases of sexual debility. }\end{array}$ \\
\hline 4 & $\begin{array}{l}\text { Aegle marmelos (L.) } \\
\text { Corr. }\end{array}$ & & Rutaceae & Leaf & $\begin{array}{l}\text { Leaf decoction is used to the } \\
\text { treatment of diabetes }\end{array}$ \\
\hline 5 & $\begin{array}{ll}\text { Andrographis } & \\
\text { paniculata } & \text { (Burm.f.) } \\
\text { Wall. ex Ness } & \end{array}$ & Kariyatu & Acanthaceae & $\begin{array}{l}\text { Leaf, } \\
\text { Seed }\end{array}$ & $\begin{array}{l}\text { Fresh leaf juice is given to prevent } \\
\text { excessive bleeding during periods. } \\
\text { Kalmegh is extremely bitter } \\
\text { medicinal herb useful in blood } \\
\text { purification. }\end{array}$ \\
\hline 6 & $\begin{array}{l}\text { Azadirachta indica A. } \\
\text { Juss. }\end{array}$ & Limbdo & Meliaceace & Leaf & $\begin{array}{l}\text { Azadirachta indica leaves are used } \\
\text { for treating chicken pox. Neem leaf } \\
\text { is helpful in curing various skin }\end{array}$ \\
\hline
\end{tabular}




\begin{tabular}{|c|c|c|c|c|c|}
\hline & & & & & $\begin{array}{l}\text { infections such as eczema, scabies, } \\
\text { and itching. }\end{array}$ \\
\hline 7 & $\begin{array}{l}\text { Bacopa monnieri (L.) } \\
\text { Wettst. }\end{array}$ & .) Brahmi & $\begin{array}{l}\text { Scrophulariacea } \\
\text { e }\end{array}$ & Leaf & $\begin{array}{l}\text { Decoction of leaves is taken to cure } \\
\text { urinary diseases. Brain health tonic, } \\
\text { improve liver health, normal blood } \\
\text { pressure, loss of hair and sleep } \\
\text { disorder. }\end{array}$ \\
\hline 8 & $\begin{array}{l}\text { Bryonia lacinosa (L.) } \\
\text { Naud. }\end{array}$ & .) Shivlingi & Cucurbiataceae & $\begin{array}{l}\text { Leaf, } \\
\text { Seeds }\end{array}$ & $\begin{array}{l}\text { The leaf extract is used for the } \\
\text { treatment of Cathartic. The seed } \\
\text { powder is used for increasing sperm } \\
\text { count. The seeds of Shivlingi, taken } \\
\text { with milk, promote the conception. } \\
\text { After the periods, 6-9 seeds are } \\
\text { given to the woman for } 5 \text { days. }\end{array}$ \\
\hline 9 & Carica papaya $\mathrm{L}$. & Papaya & Caricaceae & $\begin{array}{l}\text { Leaf, } \\
\text { Root }\end{array}$ & $\begin{array}{l}\text { Extracts from papaya roots are used } \\
\text { to abort early pregnancy. The papaya } \\
\text { leaf juice is used in treating dengue } \\
\text { fever. It helps in increasing the } \\
\text { platelet count in a dengue patient. }\end{array}$ \\
\hline 10 & Cassia occidentalis L. & $\begin{array}{l}\text { Kasundar } \\
\text { o }\end{array}$ & Fabaceae & Leaf & $\begin{array}{l}\text { Leaf juice extract used as a skin } \\
\text { diseases, ring worm, throat infection } \\
\text { and wounds. Leaf paste is externally } \\
\text { applied to curing muscles pain. }\end{array}$ \\
\hline 11 & Citrus medica $\mathrm{L}$. & Bijora & Rutaceae & Fruits & $\begin{array}{l}\text { Fruits are useful in the treatment of } \\
\text { cardiovascular health. It is also } \\
\text { helpful in kidney and bladder stone } \\
\text { problem. }\end{array}$ \\
\hline 12 & $\begin{array}{l}\text { Cocculus hirsutus (L.) } \\
\text { W. Theob. }\end{array}$ & $\begin{array}{l}\text { Vasan } \\
\text { Vel }\end{array}$ & $\begin{array}{l}\text { Menispermacea } \\
\mathrm{e}\end{array}$ & Leaf & $\begin{array}{l}\text { Leaf juice extraction, They have } \\
\text { cooling effect on body and are useful } \\
\text { in female disorders, general } \\
\text { weakness, skin diseases. Eating raw } \\
\text { fresh leaves gives relief in tiredness. }\end{array}$ \\
\hline 13 & $\begin{array}{l}\text { Cucurbita maxima } \\
\text { Duchesne ex Lam. }\end{array}$ & a Kolu & Cucurbiataceae & Fruit & $\begin{array}{l}\text { Pumpkin eating is useful for diabetes } \\
\text { patient, improving liver function. }\end{array}$ \\
\hline 14 & $\begin{array}{l}\text { Curculigo orchiodes } \\
\text { Gaertn. }\end{array}$ & $\begin{array}{l}\text { Musli } \\
\text { kali }\end{array}$ & $\begin{array}{l}\text { Amaryllidaceac } \\
\text { e }\end{array}$ & Root & $\begin{array}{l}\text { Take root powder in dose of } 5-10 \\
\text { grams with milk, it is useful } \\
\text { treatment for reduces stress. It } \\
\text { stimulates male sex hormones. }\end{array}$ \\
\hline 15 & $\begin{array}{l}\text { Cymbopogan } \\
\text { (DC.) Stapf. }\end{array}$ & sLili cha & Poaceae & Leaf & $\begin{array}{l}\text { Decoction of Lemon grass is used to } \\
\text { help control and normalize heart rate } \\
\text { and for pressure. }\end{array}$ \\
\hline 16 & Dalbergia sissoo Roxb. & $\begin{array}{l}\text { Moto } \\
\text { Sisam }\end{array}$ & Fabaceae & Leaf & $\begin{array}{l}\text { Leaf decoction is useful for cancer } \\
\text { treatment .leaf paste is externally } \\
\text { applied on cancer tumors injury. }\end{array}$ \\
\hline 17 & $\begin{array}{l}\text { Desmodium gangeticum } \\
\text { (L.) DC. }\end{array}$ & $n$ Salparni & Fabaceae & $\begin{array}{l}\text { Leaf, } \\
\text { Root }\end{array}$ & $\begin{array}{l}\text { A decoction of the leaves is used } \\
\text { against stones in the gall bladder, }\end{array}$ \\
\hline
\end{tabular}




\begin{tabular}{|c|c|c|c|c|c|}
\hline & & & & & $\begin{array}{l}\text { kidneys or bladder. The roots are } \\
\text { chewed for the treatment of } \\
\text { premature ejaculation. }\end{array}$ \\
\hline 18 & $\begin{array}{l}\text { Dolichandrone } \\
\text { atrovirens (Heyne ex } \\
\text { Roth) Sprague }\end{array}$ & Padri & Bignoniaceae & Bark & Bark decoction used for heart tonic. \\
\hline 19 & $\begin{array}{l}\text { Emblica } \\
\text { Gaertn. }\end{array}$ & Ambla & Euphorbiaceace & Fruit & $\begin{array}{l}\text { Fruit juice very energetic. It is also } \\
\text { helpful in treatment of skin and eye } \\
\text { diseases. }\end{array}$ \\
\hline 20 & Entada rheedii Spreng. & Kayri vel & Mimosaceae & $\begin{array}{l}\text { Bark, } \\
\text { Fruit }\end{array}$ & $\begin{array}{l}\text { Bark decoction is useful treatment } \\
\text { for snake bite. It is also useful } \\
\text { treatment for controlling blood } \\
\text { pressure. Seed paste is applied on } \\
\text { joints to curing joints pain. }\end{array}$ \\
\hline 21 & $\begin{array}{l}\text { Flemingia } \\
\text { Dalzell. }\end{array}$ & Bhadeli & Fabaceae & Root & $\begin{array}{l}\text { Roots are edible. It contain high } \\
\text { amount of Iron. It is very useful in } \\
\text { eating during pregnancy. }\end{array}$ \\
\hline 22 & $\begin{array}{l}\text { Hemidesmus indicus (L.) } \\
\text { Schult. }\end{array}$ & $\begin{array}{l}\text { Anantam } \\
\text { ool }\end{array}$ & Periplocaceae & Leaf & $\begin{array}{l}\text { The leaves of the plant are used for } \\
\text { gums diseases in teeth. }\end{array}$ \\
\hline 23 & Hibiscus sabdariffa $\mathrm{L}$. & $\begin{array}{l}\text { Khatadi } \\
\text { bhaji }\end{array}$ & Malvaceae & Leaf & $\begin{array}{l}\text { Leaf is roasted and then prepared to } \\
\text { chatni called "khatadi bhaji chatni". } \\
\text { It contain high amount of vitamin - } \\
\text { C. It improves natural immunity in } \\
\text { the body. }\end{array}$ \\
\hline 24 & $\begin{array}{l}\text { Hollarhena pubescens } \\
\text { (Buch. Ham.)Wall. Ex } \\
\text { G. Don }\end{array}$ & $\begin{array}{l}\text { Kadvo } \\
\text { Indrajav }\end{array}$ & Apocynaceae & seed & $\begin{array}{l}\text { The seeds are used for curing fever } \\
\text { and cold. It is also used for toning } \\
\text { up vaginal tissue after delivery in } \\
\text { women. Seed powder useful } \\
\text { treatment for diabetes, improving } \\
\text { kidney health. It is also used to clean } \\
\text { and promote milk in nursing } \\
\text { mothers. }\end{array}$ \\
\hline 25 & $\begin{array}{l}\text { Holoptelea integrifolia } \\
\text { (Roxb.) Planch. }\end{array}$ & Kanji & Ulmaceae & Bark & $\begin{array}{l}\text { The bark decoction is useful } \\
\text { treatment to curing blood purifier. }\end{array}$ \\
\hline 26 & $\begin{array}{l}\text { Ipomoea sepiaria } \\
\text { Koenig ex. Roxb. }\end{array}$ & Laxmana & Convolvulaceae & Root & $\begin{array}{l}\text { Root decoction is used for } \\
\text { gynecological disorder. }\end{array}$ \\
\hline 27 & $\begin{array}{l}\text { Kalanchoe Pinnata } \\
\text { (Lam.) }\end{array}$ & Panfuti & Crassulaceae & Leaf & $\begin{array}{l}\text { Leaves of this plant are very good } \\
\text { for removing kidney stone and } \\
\text { multiple small gall bladder stone. }\end{array}$ \\
\hline 28 & Lagenaria siceraria (L.) & Dudhi & Cucurbitaceae & Fruit & $\begin{array}{l}\text { The cooked vegetable. Bottle guard } \\
\text { juice helpful treatment for weigh } \\
\text { loose. Improving digestion, regulate } \\
\text { blood pressure, improve kidney and } \\
\text { liver function. }\end{array}$ \\
\hline 29 & Leptadenia & Jivanti & Asclepiadaceae & Stem & A stem decoction is also taken as a \\
\hline
\end{tabular}




\begin{tabular}{|c|c|c|c|c|c|}
\hline & (Retz.) W\&A. & dodi & & & $\begin{array}{l}\text { tonic and to treat diabetes. The aerial } \\
\text { parts, called 'Jivanti' or 'Dodi', are } \\
\text { widely used in tonic that boosts } \\
\text { energy level of the body. }\end{array}$ \\
\hline 30 & Mangifera indica $\mathrm{L}$. & Ambo & Anacardiaceae & Leaf & $\begin{array}{l}\text { Mango leaf decoction is used as } \\
\text { treatment of diabetes. }\end{array}$ \\
\hline 31 & $\begin{array}{l}\text { Marsdenia tenacissima } \\
\text { (Roxb.) Moon }\end{array}$ & $a$ Murva & Asclepiadaceae & Root & $\begin{array}{l}\text { Root decoction is helpful treatment } \\
\text { for curing diabetes and improving } \\
\text { strength of cardiac muscles. }\end{array}$ \\
\hline 32 & Moringa oleifera Lam. & Saragvo & Moringaceae & $\begin{array}{l}\text { Leaf, } \\
\text { Bark }\end{array}$ & $\begin{array}{l}\text { Pregnant ladies should be given } \\
\text { cooked leaves especially in last } \\
\text { trimester for easy delivery. It also } \\
\text { improves immunity. Leaves are } \\
\text { helpful in treating Menstrual cramps. } \\
\text { Drumstick seeds are helpful } \\
\text { in treating male impotency. }\end{array}$ \\
\hline 33 & $\begin{array}{l}\text { Mucuna pruriens (L.) } \\
\text { DC. }\end{array}$ & Kavach & Fabaceae & Seed & $\begin{array}{l}\text { The velvet bean can also help } \\
\text { improve skin texture and } \\
\text { appearance.. It helps men to have } \\
\text { longer sex as it increases libido in } \\
\text { both men and women. }\end{array}$ \\
\hline 34 & $\begin{array}{l}\text { Nelumbo } \\
\text { Gaertn. }\end{array}$ & a Kamal & Nelumbonaceae & Seeds & $\begin{array}{l}\text { The seeds are used to treat weak } \\
\text { sexual function in men and } \\
\text { leucorrhoea in women. }\end{array}$ \\
\hline 35 & Ocimum tenuiflorum L. & Tulsi & Lamiaceae & Leaf & $\begin{array}{l}\text { Leaf paste is applied externally on } \\
\text { forehead to get relief from headache. } \\
\text { It is also helpful in treatment of } \\
\text { respiratory disorder, it god tonic for } \\
\text { nervous system, improve digestion } \\
\text { system. }\end{array}$ \\
\hline 36 & Phaseolus vulgaris $\mathrm{L}$. & Udad & Fabaceae & Seeds & $\begin{array}{l}\text { Pods are commonly used as } \\
\text { vegetable. It is very powerful for } \\
\text { treatment of improve sexual power } \\
\text { and boost up immunity in the body. }\end{array}$ \\
\hline 37 & piper betle $\mathrm{L}$. & Nagarvel & Piperaceae & Leaf & $\begin{array}{l}\text { Chewing nagarvel pan is good for } \\
\text { digestion. }\end{array}$ \\
\hline 38 & $\begin{array}{l}\text { Pongamia pinnata (L.) } \\
\text { Pierre }\end{array}$ & Karanj & Fabaceae & $\begin{array}{l}\text { Leaf, } \\
\text { Stem }\end{array}$ & $\begin{array}{l}\text { Stem used for best tooth brush. It is } \\
\text { best mouth freshener. Leaf paste is } \\
\text { useful for the treatment of skin } \\
\text { diseases. }\end{array}$ \\
\hline 39 & $\begin{array}{l}\text { Pterocarpus marsupium } \\
\text { Roxb. }\end{array}$ & $n$ Biyo & Leguminosae & Bark & $\begin{array}{l}\text { Bark decoction is used to treatment } \\
\text { of diabetes, blood purifier and } \\
\text { improve digestive system. }\end{array}$ \\
\hline 40 & $\begin{array}{l}\text { Pueraria tuberosa } \\
\text { (Roxb. ex Willd) DC. }\end{array}$ & aPhagvelo & Fabaceae & Root & $\begin{array}{l}\text { Cook it and eat. It purifies blood and } \\
\text { cures all blood related disorder. It } \\
\text { improves and enhances sexual }\end{array}$ \\
\hline
\end{tabular}




\begin{tabular}{|c|c|c|c|c|c|}
\hline & & & & & $\begin{array}{l}\text { desire. Take } 3-6 \mathrm{gm} \text { of its powder } \\
\text { with boiled milk, regularly. It delays } \\
\text { ageing. }\end{array}$ \\
\hline 41 & Rubia cordifolia $\mathrm{L}$. & Majith & Rubiaceae & Root & $\begin{array}{l}\text { Root decoction is helpful for blood } \\
\text { purification and skin diseases. Take } \\
\text { Root decoction powder daily to } \\
\text { improve skin glow. }\end{array}$ \\
\hline 42 & Ruellia tuberosa $\mathrm{L}$. & $\begin{array}{l}\text { Bandhuk } \\
\text { adi }\end{array}$ & Acanthaceae & Leaf & $\begin{array}{l}\text { Leaf decoction drunk by pregnant } \\
\text { women for cold in the body }\end{array}$ \\
\hline 43 & $\begin{array}{l}\text { Saraca asoca (Roxb.) de } \\
\text { Wilde. }\end{array}$ & eAshok & Caesalpiniaceae & $\begin{array}{l}\text { Bark, } \\
\text { Seed }\end{array}$ & $\begin{array}{l}\text { Bark decoction is used to control } \\
\text { irregular menstrual cycles. Ashoka } \\
\text { tree seed power is a natural method } \\
\text { to control kidney stones. }\end{array}$ \\
\hline 44 & Sphaeranthus indica $\mathrm{L}$. & $\begin{array}{l}\text { Gorakhm } \\
\text { undi }\end{array}$ & Asteraceae & Flower & $\begin{array}{l}\text { Flower Heads are Blood purifier in } \\
\text { skin diseases. }\end{array}$ \\
\hline 45 & $\begin{array}{l}\text { Tinospora cordifolic } \\
\text { (Willd.) Miers ex Hook } \\
\text { f. and Tho. }\end{array}$ & $a$ Galo & $\begin{array}{l}\text { Menispermacea } \\
\text { e }\end{array}$ & Stem & $\begin{array}{l}\text { Galo is king of medicine. } \\
\text { Decoction of stem is given thrice a } \\
\text { day in fever. Decoction of stem is } \\
\text { taken orally once a day to control } \\
\text { diabetes. }\end{array}$ \\
\hline 46 & Trapa bispinosa Roxb. & Shingoda & Trapaceae & Fruits & $\begin{array}{l}\text { Fruits are eaten cooked. It is used in } \\
\text { improve sexual potency. Also used } \\
\text { in treat women suffering from } \\
\text { threatened abortion. }\end{array}$ \\
\hline 47 & Vitex negundo L. & Nagod & Verbenaceae & Leaf & $\begin{array}{l}\text { Leaf juice is applied on swollen } \\
\text { body parts to reduce pain and } \\
\text { tiredness. }\end{array}$ \\
\hline 48 & $\begin{array}{l}\text { Withania somnifera }(\mathrm{L} \text {.) } \\
\text { Dunal. }\end{array}$ & $\begin{array}{l}\text { Ashwaga } \\
\text { ndha }\end{array}$ & Solanaceae & $\begin{array}{l}\text { Leaf, } \\
\text { Root }\end{array}$ & $\begin{array}{l}\text { Root powder is taken with milk } \\
\text { twice a day in cases of general } \\
\text { debility. For reducing weight, one } \\
\text { leaf is taken empty stomach in the } \\
\text { morning Leaf paste used in treatment } \\
\text { of eczema, acnes, swallon skin. }\end{array}$ \\
\hline 49 & $\begin{array}{l}\text { Woodfordia } \\
\text { (Linn.) Kurz }\end{array}$ & aDhavdo & Lythraceae & Seeds & $\begin{array}{l}\text { Dried seed of powder take } 2 \text { to } 3 \\
\text { pinches with milk twice a day use to } \\
\text { control menstrual disorder. }\end{array}$ \\
\hline 50 & $\begin{array}{l}\text { Zinziber } \\
\text { Roscoe. }\end{array}$ & eAadu & Zingiberaceae & $\begin{array}{l}\text { Rhizom } \\
\text { e }\end{array}$ & $\begin{array}{l}\text { Take Ginger juice is used to cure } \\
\text { digestive disorder, cough, could, } \\
\text { respiratory disorder, heart diseases } \\
\text { and also used in } 30 \text { ml zinger juice is } \\
\text { used in early morning empty } \\
\text { stomach it is very useful in } \\
\text { pancreases health. }\end{array}$ \\
\hline
\end{tabular}


In conclusion, the tribal people have been using various plants species for using medicinal and other plants product. Most of the medicinal plants are getting very rare as confirmed by traditional healers and as observed during the field work too. Deforestation, overgrazing are major factors that affect different medicinal plants. Therefore encouraging the people to grow different medicinal plants species in the farm and protected the forest wild plants species for incoming future.

\section{Acknowledgement}

The authors are very grateful to Kaprada forest tribal people for providing us the maximum indigenous knowledge to inquiry details regarding the collection and identification of medicinal plants species. People and traditional healers also helped in during the field visit.

\section{References}

Almeida, M.R. 2003. Flora of Maharashtra. Vol. 1-2. Orient Press, Mumbai.

Chopra, R.N., Nayar, S.L. and Chpora, I. C. 1956. Glossary of Indian medicinal plants. Council of Scientific and Industrial Research, New Delhi.

Cooke, T. 1958. Flora of the Presidency of Bombay: Vol. 1, 2, and 3. Botanical Survey of India, Calcutta (reprint).

Cotton, C. M. 1997. Ethnobotany: Principles and Applications. John Wiley and Sons. New York.

Cotton, C. M. 1996. Ethnobotany Principal and Applications. Jhon Wiley and Sons, Chishester, New York, Brisbane, Toronto, Singapore.

Gohil, T.G. and Thakor, A.B. 2008. Ethnobotanical uses of plants by tribals of Kaparada taluka in Valsad District of Gujarat, INDIA. International Journal of Plant
Sciences, Vol. 3 No. 2: 650-653.

Inamdar, J.A. 1966. A preliminary survey of the flora of Dharampur forests in Gujarat. Bull.Bot.Survy.India.10:126132.

Jain, A., Katewa, S.S., Galav, P.K. and Sharma, P. 2005b. Medicinal plant diversity from the Sitamata wild life sanctuary. Chittorgarh district India. J. Ethnopharmacology 102 (3): 543-557

Jain, S. K. 1991. Dictionary of Indian Folk Medicine and Ethnobotany. Deep publications, New Delhi: 311. John Wiley and Sons. New York.

Kirtikar, K.R. and Basu, B.D. 1993. In: Blatter, E., Caius, J.F. and Mhaskar, K.S., Editors, Indian Medicinal Plants I-IV, Lalit Mohan Basu, Allahabad, India.

Martin, G. 1995. Ethnobotany- A Methods Manual. Pp 1-268.

Patel R. S. 2002. Ethnobotany of Ambaji forest of North Gujarat. Ph. D. Thesis Submitted to Sardar Patel University, Vallabh Vidhyanagar.

Patel, H.S. 2011. Medicinal Plant Diversity and Ethnomedicobotany of Kaprada range of Dharampur Forests in South Gujarat. Thesis submitted to Department of forestry Aspee College of horticulture and forestry Navsari agricultural university Navsari, Gujarat.

Patel, R. M. 1971. The Flora of Bulsar and its environs. Thesis submitted to S. P. Univ., Vallabh Vidhyanagar. Gujarat.

Rao, V.H., Gohil, T.G and Thakor A.B. (2013). Floristic study of kaparada forest in south Gujarat. International Journal of plant science, Vol. 8(1), 100-102.

Rastogi R P and Mehrotra B N (ed.). Compendium of Indian Medicinal Plants, Volume 1(1990), 2(1991), 3(1993) 4(1995), 5(1998). Published by Central Drug Research Institute, 
Luckhnow and National Institute of Science Communication, New Delhi.

Reddy, A. S. (1987). Flora of Dharampur Forest Part 1 and 2. Ph. D. Thesis, Department of biosciences, Sardar Patel University, Vallabh Vidhyanagar.

Shah, G. L. (1978). The flora of Gujarat State.
Vol I and II. Registrar, Sardar Patel University, Vallabh Vidhyanagar, Gujarat (India).

Vora, H. M. (1980). A contribution to the Flora of Dharampur, Kaprada and Nana Pondha ranges. Thesis submitted to S. P. Univ. Vallabh Vidyanagar. Gujarat.

\section{How to cite this article:}

Patel Dharmesh, C. and Jat, B.L. 2018. An Ethnobotanical Survey of Medicinal Plants Used by Traditional Healers of Kaprada Forest (Valsad District), Gujarat, India. Int.J.Curr.Microbiol.App.Sci. 7(07): 2034-2043. doi: https://doi.org/10.20546/ijcmas.2018.707.240 